\title{
Analysis of Supply Chain Performance of Staple Foodstuffs using Triadic Approach
}

\author{
Chairul Furqon ${ }^{1 *}$, Mokh. Adib Sultan ${ }^{1}$, Andjar Rasmita Adji ${ }^{1}$ \\ ${ }^{1}$ Management Study Program, UniversitasPendidikan Indonesia, Jl. Dr. Setiabudhi No. 229 \\ Bandung, 40154, Indonesia, \\ *c_furqon@upi.edu
}

\begin{abstract}
The need for staple foodstuffs for a community is very vital. Problems that arise are mainly related to efficient fulfillment, as happened in Bandungcity, Indonesia. This study aims to obtain an overview and performance of the staplefoodstuffssupply chain in Bandung. The study used a qualitative approach with descriptive analysis methods, observations and in-depth interviews conducted to collect research data. The results showed that from observing market structure, market behavior, and processing staple food information, it can be seen that the distribution of staple foods in Bandung, is very time-consuming and costly, as well as being dependent on other cities for their fulfillment.Based on these conditions, an analysis of supply chain performance is carried out using a triadic approach that sees from the point of view starting from upstream, midstream, to downstream.Basically, to improve supply chain performance, it needs to be understood by all supply chain members to maintain relationships quality, that indicated by: trust, commitment, conflict resolution, and so on.If it is maintained, efficiency, and responsiveness of supply chain will be more manageable.
\end{abstract}

Keywords: Supply chain performance, triadic approach, relationship quality.

\section{Introduction}

The development of the 4.0 Industrial Revolution had a significant impact on various sectors. Likewise with the industrial sector related to staple food needs. Many studies show that today a company no longer competes independently, but rather as a supply chain.1-4 There is increasing interest from experts and researchers about evaluating the importance of supply chain performance in the field of food and foodstuffs and exploring the main factors that influence it.5-8 One of the factors influencing supply chain performance is relationship quality, and is said to be the main factor that has the most important influence.9,10,6,8 Relationship quality represents the degree of supply chain members involved in long-term relationship activities based on their past successes and failures, and is an answer to basic needs and expectations.11-12

Meeting staple foodstuffs needs requires supply chain stability. This can be achieved if the members of the supply chain have a good relationship quality. Relationship quality is a concept of social psychology derived variables such as trust, commitment, and satisfaction.1316 The study of tracking the combined effects of the relationship quality component on supply chain performance is very little compared to the study of the impact of the relationship quality component on supply chain performance which is the majority.9,6,8 Therefore, there is little evidence from the literature that the quality of relationships measured at the aggregate level affects supply chain performance. 
This research focuses on the supply chain of staple foodstuffs. In Indonesia, staple foodstuffs consist of nine kinds, namely: sugar, vegetables and fruit, beef and chicken or chicken eggs, iodized salt, cooking oil or margarine, corn, kerosene or LPG, and milk (Decree of Minister of Industry and Trade No.115/ mpp/mp/2/1998). The problem is, the supply chain of staple foodstuffs is not efficient, especially in the city of Bandung. Previous research also shows that the basic necessities play a vital role in the needs of the people of Indonesia, so that if they are not fulfilled, they will be very fatal, so they must be free on the market.17 Over time, only a few staple foodstuffs are deemed to have more priority and are fatal as a result if not met, namely rice, chicken meat or eggs, vegetables or fruit, and LPG. The general objective to be achieved in this research is to find out the description of the process and performance of the supply chain in the field of staple foodstuffs in Bandung.

\subsection{Literature Review}

Initially, there were many studies on supply chain performance that analyzed the performance of a business unit from only one perspective or individually within the framework of the supply chain $18,4,19$, or through two perspectives, also called the dyadic approach method. 20,9,21,22,19,23 The dyadic approach method obtains data from two upstream or downstream business units with focal companies20, but previous research revealed that this dyadic approach method cannot reveal the basic dimensions of a supply chain.24-26 Then came the desire of the researchers to analyze the supply chain from the three points of view of the companies that are simultaneously connected or the Triadic approach which includes suppliers, focal companies, and consumers.6,27But only a few apply because of the level of complexity that must be faced when collecting data using this approach, especially in the field of foodstuffs. $6,25,26,8$

The industry in the field of foodstuffs and traditional food is one of the industries that has developed 28, and is a concern of scientific literature.29-31 This interest turned out to be comprehensive at the level of producers, industry, government, retailers, and consumers.28,31-33 The process of research on the supply chain has been very much done, but only a few have examined a whole supply chain system from upstream to downstream or called the Triadic approach. Due to the difficulty of finding data and the cost is not small.

Knowing the role of a food supply chain is a must for human survival. Evaluation of supply chain performance is very important, because it will have an impact on the activities of meeting the needs of human life. It needs to be understood by each member of the supply chain how the role of relationship quality on supply chain performance.As a developing country whose economic conditions are improving, Indonesia must pay attention to the food fulfillment sector which is still an obstacle because of the many challenges faced.35 This research was conducted in order to provide more empirical evidence about how the importance of supply chains in the food sector and how the pattern of relationship quality affects the performance of the supply chain.

\subsection{Supply Chain Management}

Supply chain management is an integration of a series of activities ranging from the procurement of raw materials in the form of materials and services which are then converted into work-in-processed or finished goods, and distributed to consumers.34 Supply Chain is the company's involvement in the manufacture and distribution of goods or services as a series of facilities, functions and activities of the company. The series starts with the supplier and ends with the final customer.35 Supply chain management is a set of approaches to streamline the integration of suppliers, manufactures, warehouses and storage, so that goods are produced 
and distributed in the right amount, the right location, the right time, with the aim of achieving minimum costs and providing customer satisfaction. Supply chain management talks about two main or key points of the main topic namely efficiency and effectiveness. So, supply chain management will focus heavily on how the flow of goods and services and information has a high level of responsiveness to minimizing costs and maximizing customer satisfaction in an integrated manner through the chain. In general, supply chain management strategies include: 1) many suppliers, 2) few suppliers, 3) vertical integration, 4) keiretsu networking, and 5) virtual companies.34

\subsection{Relationship Quality}

Quality can be defined as dynamic conditions related to products, services, human resources, processes, and the environment as expected.36 From the Manufacturing-based Approach point of view, quality is supply-based or from the point of view of the manufacturer that defines quality as conformance quality and procedure. This approach focuses on conforming to the specifications set by the company internally. Therefore, what determines quality is the standards set by the company, and not the customers who determine it.37 Relationship Quality is a series of episodes of corporate interaction that occur between two parties with consumers within a certain timeframe to establish relationships with quality that achieve a common goal.38 Relationship quality has been considered a higher order construction and an important role in customer decision making or post-purchase processes in the marketing concept.38 This has been seen as one important indicator that measures the strength of customer relationships.39 Relationship quality is a major factor influencing customer repurchase behavior.38 Relationship quality is an effort to build a higher order and consists of several different dimensions. Previous studies have revealed various conceptualizations. Most previous research considers trust, commitment and satisfaction as the main variables that produce the quality of successful relationships.38

Supply Chain performance and Relationship Quality in this context are based on Social Network Theory (SNT) which shows that companies are trying to make a close relationship so that public benefits can be achieved.8 According to SNT, organizations should not be studied in isolation because they are ultimately influenced by their own networks.40 A supply chain contains producers, suppliers, and consumers who are part of the upstream or downstream flow of a product, service, or information. 24 The food supply chain deals with a variety of activities: procurement of agricultural raw materials, their processing to the end of human consumption and distribution.41 The feasibility function of the supply chain depends on their members whose main purpose is to provide customer demand satisfaction in working together in the process of adding value.42 Fulfilling the common interests of supply chain members is the success of the supply chain as a whole, while also providing competitive advantages for individual members. Therefore, in today's competitive market, it is very important for members of different supply chains to understand their respective roles in order to maintain the quality of relationships in the supply chain. 6,42

\section{Method}

The object of this research is supply chain performance which is assessed using a triadic approach. This study uses a qualitative approach with descriptive analysis methods and support of quantitative data. Literature studies, observations, in-depth interviews are 
conducted to collect research data. There are several things that are used as a benchmark in determining research questions as well as an indicator in assessing the performance of this supply chain, among others, seen from the market structure of the product under study, market behavior, and the chain of business governance. The triadic approach itself requires the role of relationship quality whose main elements include; trust, satisfaction and commitment. This approach looks at the quality of relationships from three points of view, starting from upstream, focal companies, and downstream. This research seeks to collect data from producers/suppliers of basic foodstuffs, focal companies which, among others, are related to the government, such as the National Logistics Agency, the Food Security and Agriculture Office, and the community as consumers. Based on the calculation results, the sample size obtained by 96 people, the number consists of members of the supply chain for staple foodstuffs needs in the city of Bandung.

\section{Results And Discussion}

Based on the results of data collection through literature studies, observations and interviews, obtained data as follows. Some of the staples in Bandung studied include beef, chicken, rice, and so on. However, for the purposes of analysis, only one sample will be presented given the characteristics of the staple food, some are almost the same.

The staple food that will be raised is beef, seen from the market structure and market behavior, it can be stated as follows. In Bandung city, marketing of local cows and imported cows has a different market structure, as well as marketing of beef. Local cattle marketing in the animal market is a market with a perfectly competitive structure, because in the animal market there are many cattle traders with almost the same type of local cattle, and prices are not too far between one trader and another trader, which determines the best price is the performance of the cow itself. The marketing of imported cattle approaches the oligopoly market structure, because there are only a few companies importing cattle, and those who enter Bandung are dominant from Bandung Regency and others Regency, with the same type of cattle and the same price, if the quality of the cow is not much different. After entering the abattoir, cattle entrepreneurs in the abattoir determine the price that cannot be bargained, there are only a few entrepreneurs who offer cattle at almost the same price, traders simply choose the cattle they want without a lot of bargaining.

The marketing of fresh beef in the retail market has a perfectly competitive market structure, because the trade of cattle in traditional markets and supermarkets and meat stalls has the following characteristics: a) the amount of meat marketed is homogeneous, generally coming from cattle that have the lowest value, for example cattle imports are cheap then the type of beef that meets the market, b) there are many meat traders in one traditional market location, or there are many supermarkets selling beef in the city of Bandung, c) a strong consumer bargaining position, where consumers will buy meat if prices offered by traders is considered reasonable, d) because of the large number of beef traders in a location, it is difficult for traders to take profits above the average, e) price sensitive, where an increase in price will impact on sales turnover, both for the Slaughterhouse and retailer.

The tendency of consumers to buy a product, which is market behavior, especially for beef can be described as follows. In general, there are fewer consumers coming from households compared to industrial / processing consumers. If beef is considered too expensive for daily food consumption, household consumers prefer processed products, such as satay, shredded, or others. But marketing beef will increase sharply during Eid and welcome fasting, because 
it is a tradition in Bandung city to process beef into various dishes. During this Eid, the price of beef, even though it is offered at a high price, will still be bought by consumers. Somewhat different from the behavior of the industry where the consumers are among others, from processors, both serving rice stalls, cafes, restaurants, traders, meatball processors, shredded processors, and satay traders. They will choose meat based on consideration of the availability of meat, the price can be prioritized, because if the price is high the processor will raise the price of its processed products, so that profits remain optimal. More clearly the distribution channel of cattle and beef in the city of Bandung can be seen from figure 1.

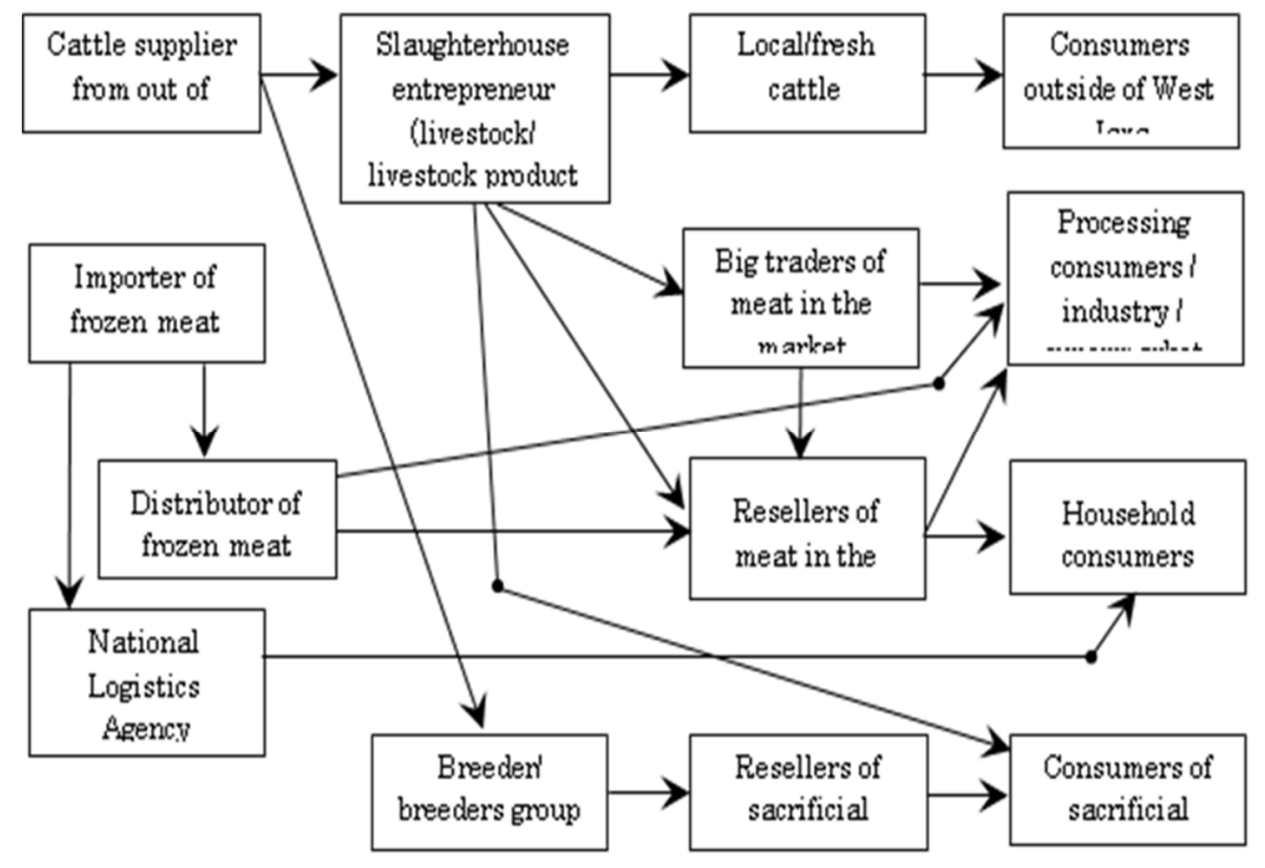

Figure.1. Distribution channel of cattle \& beef in Bandung city

Based on the example of the distribution channel in figure 1, it can be seen that in reality the distribution of staple foods in Bandung is quite complex. Considering that the beef consumed by the community comes from cattle and some comes from imported frozen meat. Market behavior also determines the supply chain evaluation. The most important main step in evaluating supply chains is to have a clear definition of supply chain objectives as they relate to their performance. The purpose of the supply chain is an achievement that can be achieved only if all members of the supply chain work together to eliminate existing obstacles. 43

A performance can be generally measured subjectively and objectively. The objective way to measure performance is based on company financial data or indicators such as profit, warehouse inventory, and turnover. However, many agro-food companies do not display their performance in a regular way and they are often unwilling to provide company operational financial information.

Therefore, there is a subjective way of measuring performance based on the subjective opinion and the assessment or perception of respondents on the performance of the business 
supply chain. Previous studies have shown that the assessment received is consistent with objective performance.44 Appropriate instruments are needed in measuring subjective performance that can quantitatively indicate how successful the supply chain is, how inter service quality is, and is expected to optimize the potential for improving performance. 45 Several other studies have shown that relationship quality is a prerequisite for high supply chain performance. Relationship quality is a comprehensive assessment of the strength of relationships and degrees that indicate the needs and desires of business partner satisfaction.19 In some literature, the quality of relationships is usually conceptualized as a composite or multidimensional construct that illustrates the interrelated factual differences of a relationship.

\section{Conclusions}

Based on observations of market structure, market behavior, and trade chain and reports on the results of information processing of staple foods from various sources, it can be concluded that there is a process that is very time-consuming and costly and the dependence of the city of Bandung on other cities in the fulfillment of staple foodstuffs. The high level of demand for basic foodstuffs in the city of Bandung, indicates the level of community dependence on basic foodstuffs, and if it is not met it has the potential to interfere with the survival of the people of Bandung. Then, there are some basic foodstuffs that rely heavily on supplies from outside the city of Bandung, and some have become an oligopoly market for large traders. However, a glimmer of hope began to emerge in the era of the Industrial Revolution 4.0, namely the application-based information technology developed by the province of West Java about food price information, although not yet optimally functioning, it is expected that in the future the problem of accuracy, speed in meeting the needs of basic food ingredients can be better.

\section{References}

[1] Christopher,M.,Logistics and Supply Chain Management Strategies for Reducing Cost and Improving Service, 2nd ed., (Financial Times: Pitman Publishing, London, 1998).

[2] Cox,A., Power, value and supply chain management, Supply Chain Management: An International Journal, Vol. 4 No.4,(1999),pp.167-175.

[3] Lambert, D.M. and Cooper, M.C., Issues in supply chain management, Industrial Marketing Management, Vol.29No.1,(2000),pp.65-83.

[4] Sezen, B., Relative effects of design, integration and information sharing on supply chain performance, Supply Chain Management: An International Journal, Vol. 13 No. 3, (2008), pp.233-240.

[5] Aramyan, L.H., OudeLansink, A.G., Van Der Vorst, J.G. and VanKooten, O., Performance measure mentinagri foodsupply chains:a case study, Supply Chain Management: An International Journal,Vol.12No.4, (2007), pp.304-315.

[6] Molnár, A., Gellynck, X. and Weaver, R.D., Chain member perception of chain performance: the role of relationship quality, Journal on Chain and Network Science, Vol.10No.1, (2010), pp.27-49.

[7] Mutonyi, S. and Gyau, A., Measuring performance of small and medium scale agrifood firms in developing countries: Gap between Theory and Practice, No 163339, 140th Seminar, 13-15 December, European Association of Agricultural Economists,Perugia.(2014) 
[8] Odongo, W., Dora, M., Molnár, A., Ongeng, D. and Gellynck, X., Performance perceptions among food supply chain members: a triadic assessment of the influence of supply chain relationship quality on supply chain performance, British Food Journal, Vol.118 No.7, (2016), pp.1783-1799.

[9] Fynes, B., Burca, S. and De Voss, C., Supply chain relationship quality, the competitive environment and performance, International Journal of Production Research, Vol.43No.16, (2005), pp.3303-3320.

[10] Lambert, D.M., Supply Chain Management: Processes, Partnerships, Performance, Supply Chain Management Institute,Sarasota,FL.(2008)

[11] Razavi, S.M., Abdi, M., Amirnequiee, S. and Ghasemi, R., The impact of supply chain relationship quality and cooperative strategy on strategic purchasing, Journal of Logistics Management,Vol.5No.1,(2016),pp.6-15.

[12] Crosby,L.A.,Evans,K.R.and Cowles,D., Relationship quality in services selling: an interpersonal influence perspective,Journal of Marketing,Vol.54No.3,(1990), pp.68-81.

[13] Moorman, C., Deshpande, R. and Zaltman, G., Factors affecting trust in market research relationships, TheJournalofMarketing,Vol.57No.1,(1993), pp.81-101.

[14] Ganesan, S., Determinantsoflong-termorientationin buyer-seller relationships, Journal of Marketing, Vol. 58 No.2, p(1994), p.1-1.

[15] Geyskens, I., Steenkamp, J.B.E. and Kumar, N., A meta-analysis of satisfaction in marketing channel relationships, Journal of Marketing Research, Vol. 36 No. 2, (1999), pp.223-238.

[16] Hennig-Thurau, T., Gwinner, K.P. \& Gremler, D.D., Understanding relationship marketing outcomes an integration of relational benefits \& relationship quality, Journal of Service Research, Vol.4 No.3, (2002), pp.230-247.

[17] Wahyuni, S., Irawan, H., \& Sofyan, E. Pengaruh Kepercayaan, Kemudahan dan Kualitas Informasi Terhadap Keputusan Pembelian Online di Situs Online Fashion Zalora.co.id. EProceeding of Management, 4(2), (2017), 1405-1412.

[18] Soonhong, M. and Mentzer, J.T., Developing and measuring supply chain management concepts, Journal of BusinessLogistics,Vol.25No.1,(2004), pp.63-99.

[19] Srinivasan,M.,Mukherjee,D.\&Gaur,A.S,Buyer-supplier partnership quality \& supply chain performance: moderating role of risks, and environmental uncertainty, EuropeanManagementJournal,Vol.29No.4,(2011), pp.260-271.

[20] Benton, W.C. and Maloni, M., The influence of power driven buyer/seller relationships on supply chain satisfaction, Journal of Operations Management, Vol. 23 No.1, (2005), pp.1-22.

[21] Krause, D.R., Handfield, R.B. and Tyler, B.B., The relationships between supplier development, commitment, social capital accumulation and performance improvement, Journal of Operations Management,Vol.25 No.2, (2007), pp.528-545.

[22] Yang,H.,Lin,Z.and Lin,Y, A multilevel framework of firm boundaries: firm characteristics, dyadic differences, and network attributes, Strategic Management Journal, Vol.31No.3,(2009), pp.237-261.

[23] Nyaga, G.N., Lynch, D.F., Marshall, D. and Ambrose, E., Power asymmetry, adaptation and collaboration in dyadicrelationships involvinga powerful partner,Journalof SupplyChainManagement,Vol.49No.3,(2013), pp.42-65.

[24] Mentzer,J.T., De Witt, W., Keebler, J.S., Min, S., Nix, N.W., Smith, C.D. and Zacharia, Z.G., Defining supply chain management, Journal of Business Logistics, Vol. 22 No.2,(2001), pp.125.

[25] Kuhne, B., Gellynck, X. and Weaver, R.D., The influence of relationship quality on the innovation capacity in traditional food chains, Supply Chain Management: An InternationalJournal,Vol.18No.1,(2013), pp.52-65.

[26] Dora, M., Role of power on supply chain performance: empirical evidence from the agribusiness sector, available at:http://bura.brunel.ac.uk/bitstream/2438/12512/1/Fulltext.pdf, (2016) 
[27] Holma, A.M., Interpersonal interaction in business triads - case studies in corporate travel purchasing, Journal of Purchasing and Supply Management, Vol. 18 No.2,(2012), pp.101-112.

[28] Vanhonacker, F., Verbeke, W., Guerrero, L., Claret, A., Contel, M., Scalvedi, L., and Granli, B.S., How European consumers define the concept of traditional food: evidence from a survey in six countries, Agri business, Vol.26 No.4, (2010), pp.453-476.

[29] Jordana, J., Traditional foods: challenges facing the European food industry, Food Research International, Vol.33 Nos3/4, (2000), pp.147-152.

[30] Wycherley, A., McCarthy, M. and Cowan, C., Speciality food orientation of food related lifestyle (FRL) segments in great britain, Food Quality Preferences, Vol. 19 No.5,(2008), pp.498-510.

[31] Cerjak, M., Haas, R., Brunner, F. and Tomic, M., What motivates consumers to buy traditional food products? Evidence from Croatia and Austria using word association and laddering interviews, British Food Journal, Vol.116No.11,(2014), pp.1726-1747.

[32] Almli, V.L., Consumer acceptance of innovations in traditional food: attitudes, expectations and perception, Doctoral Thesis, Norwegian University of Life Sciences, ISSN15031667,ISBN978-82-575-1064-0.(2012)

[33] Mesic, Ž., Božic, M. and Cerjak, M., The impact of geographical indications on the competitiveness of traditional agri-food products, Journal of Central European Agriculture,Vol.18No.1,(2017), pp.15-28.

[34] Heizer, J and Render B., Operations Management, Global Edition 11th Edition. (New Jersey: Pearson Education, 2014)

[35] Setiawan, Ahmad Ikhwan dan Reza R. Pengaruh Pola Integrasi Supply Chain Management Terhadap Performa Perusahaan Pada Industri Jasa Makanan di Surakarta. Jurnal Bisnis \& Manajemen. Vol 05, No.1.(2005).

[36] Goetsch David L. dan Davis, Stanley B. Pengantar Manajemen Mutu 2. Edisi Bahasa Indonesia. (Jakarta. PT Prenhallindo,2007)

[37] Yamit, Zulian. Manajemen Kualitas Produk \& Jasa. (Yogyakarta: Ekonesia, 2010)

[38] Huang, C. The Impact of Relationship Quality on Customer Loyalty. Semantic Scholar(2012)

[39] Garbarino, E. and Johnson, M.S. The Difference Roles of Satisfaction, Trust and Commitment in Customer Relationships. Journal of Marketing, 2,(1999), 55-59.

[40] Williams, K. and Durrance, J., Social networks and social capital: rethinking theory in community informatics, The Journal of Community Informatics, Vol.4 No.3, (2008), pp.1-20.

[41] Turi, A., Goncalves, G. and Mocan, M., Challenges and competitiveness indicators for the sustainable development of the supply chain in food industry, Procedia-Social and Behavioral Sciences, Vol.124, (2014), pp.133-141.

[42] Noémi, V., Members of a supply chain and their relationships, Applied Studies in Agribusiness and Commerce, Vol.6No.5,(2012), pp.131-134.

[43] Simatupang, T.M., Wright, A.C. and Sridharan, R., Applying the theory of constraints to supply chain collaboration, Supply Chain Management: an International Journal,Vol.9No.1,(2004), pp.57-70.

[44] Vickery,S.K.,Dröge,C.and Markland,R.E.,Dimensions of manufacturing strength in the furniture industry, Journal of Operations Management,Vol.15 No.4,(1997), pp.317-330.

[45] Cohen, S. and Roussel, J., Strategic Supply Chain Management. The Five Discipline for Top Performance, (McGraw-Hill,NewYork,NY., 2005).

[46] Palmatier, R.W., Dant, R.P., Grewal, D. and Evans, K.R., Factors influencing the effectiveness of relationship marketing: a meta-analysis, Journal of Marketing, Vol. 70 No.4,(2006), pp.136- 